\title{
The Currency Composition of Foreign Exchange Reserves: Retrospect and Prospect ${ }^{1}$
}

\section{Barry Eichengreen and Donald J. Mathieson January 2000}

\section{Introduction}

The management of international reserves remains one of the understudied aspects of the international monetary system. There are now a number of reasons why this should change. On the supply side of the market there is the advent of the euro, creating a fullfledged rival to the dollar for the first time in more than 50 years. The existence of this attractive alternative, it is said, will produce major shifts in the currency composition of international reserves, requiring large movements in the euro-dollar exchange rate to restore equilibrium to international financial markets. On the demand side there is the rush by industrial-country central banks out of gold and changes in the trade relations, capital-account restrictions, and exchange-rate regimes of developing countries, which may have important repercussions for the composition of their reserves.

${ }^{1}$ University of California at Berkeley, and International Monetary Fund, respectively. This paper was prepared for the UNU/WIDER Conference on the Future of the International Monetary and Financial System, Helsinki, 11-12 November 1999, and forthcoming in the associated conference volume. For help with the data we thank Sylvia Iorgova and Ken Wood. Charles Wyplosz provided many helpful comments. 
A number these issues have been addressed in the recent literature. ${ }^{2}$ But one of them - their impact on the currency composition of reserves -- has not been systematically addressed. We therefore analyze recent trends in currency composition in this paper, with special attention to emerging markets, where the impact of changes in the international financial environment is especially far-reaching, and with special reference to the euro, perhaps the single most important event on the reserve-currency scene.

Attempts to address these questions are hampered by lack of data. Central bankers, like others active on international financial markets, are reluctant to reveal detailed information on their currency trades and positions. They provide time series on total reserves, although not always with the speed and accuracy that one might like. These are problems that are supposed to be rectified by the requirements of the IMF's Special Data Dissemination Standard, but not even that requires them to divulge information on the currency composition of reserves. More detailed breakdowns are provided to the Fund or estimated by IMF staff in the course of Article IV surveillance and program-related consultations, but these are published in the IMF's Annual Report only for groups of countries, again on grounds of confidentiality. As Table 1 shows, these data are provided for seven major currencies and the ECU (the residual being the difference between total foreign exchange reserves and reported holdings of ECUs and the big seven currencies). The data as published distinguish industrial and developing countries. But the reporting central banks and governments continue to

${ }^{2}$ On the euro's prospective role as a reserve currency, see Alogoskoufis and Portes (1997), Bergsten (1997), Masson and Turtelboom (1997), Eichengreen (1998), Frenkel and Sondergaard (1999), and European Central Bank (1999). The role of gold, past, present and future, is analyzed by Bordo and Eichengreen (1998). Reserve management by developing countries is taken up by Feldstein (1999). We provide additional references below. 
regard the individual country data as too sensitive to make available to the public. And in their absence it is difficult to make more than rough guesses of the impact on the currency composition of reserves of changes in trade patterns, international financial markets, macroeconomic conditions, and capital-account and exchange rate regimes.

The sole exception is a decade-old study by Dooley, Lizondo and Mathieson (1989) (hereafter referred to as DLM), which used confidential IMF data to analyze the determinants of the currency composition of reserves. The composition of reserves was shown to be responsive to the choice of currency peg, the identity of the dominant trade partner, and the composition of the foreign debt. Given the changes affecting international financial markets over the intervening period, it is not clear how many of their results carry over. What was true then may not be true now.

In addition, the questions have changed. A decade ago many developing countries were just beginning to emerge from the debt crisis of the 1980s and still burdened by overhangs of foreign financial obligations; this understandably led DLM to focus on the connection between debt and reserves. The issues today are more how the term structure of the debt affects the demand for reserves, how the multilateralization and regionalization of trade has affected reserve composition, and how the level and composition of reserves are influenced by policies toward the exchange rate and the capital account.

In this paper we update the DLM data base and analysis. Again using unpublished IMF data on the currency composition of reserves for developing countries, we replicate their analysis using data for the more recent period and ask how (if at all) the historical relationships have changed. We then examine the influence of a number of additional 
determinants of the currency composition of reserves, such as the convertibility of the capital account and the choice of exchange rate regime. We focus mainly on the portfolio choices of developing countries both because this is where the impact of recent changes in market structure and policy are likely to have been most pronounced, and because much of the movement in the currency composition of industrial countries' reserves plausibly reflects the temporary effects of intervention related to exchange rate movements rather than underlying changes in portfolio preferences (Roger 1993). ${ }^{3}$

Our single most important finding is the striking stability over time not just of the currency composition of reserves but also of the relationship between the demand for reserves denominated in different currencies and its principal determinants: trade flows, financial flows and currency pegs. ${ }^{4}$ This is not something that would have been predicted from recent contributions to the literature, which have forecast sharp shifts in the currency composition of central banks' holdings of foreign exchange. The message would seem to be that in this, as in other respects, the international monetary system is in a mode of gradual, continuous evolution, not of rapid, discontinuous change. For the same reasons that, say, the share of countries operating a particular exchange-rate arrangement tends to evolve gradually (rather than to shift all at once in response to some grand scheme for a new Bretton Woods or a global system of target zones), the composition of reserves similarly appears to evolve only gradually, despite the existence of quite marked changes in the wider financial environment. If

${ }^{3}$ Our most important findings appear to apply to the industrial as well as developing countries, although the former are not the focus of this paper.

${ }^{4}$ As anticipated in the previous footnote, limited analysis for the industrial countries points quite strongly to the same conclusion. 
the right metaphor is punctuated equilibrium, then we would appear to be in one of those long periods between punctuation marks.

\section{Background}

None of this is to deny that these gradual movements have cumulated into some notable changes in the currency composition of international reserves over the last few decades. As Figure 1 shows, the dollar's share has fallen over the last quarter century from its position of unrivaled dominance in the Bretton Woods period. Much of this movement is explicable in terms of the declining share of the United States in global output (Bergsten 1997). However, the sharpest downward movement was in the late 1970s, a period of high inflation and macroeconomic instability in the United States. Between 1987 and 1990, the share of the dollar in global foreign exchange reserves again fell sharply, a shift entirely accounted for by shifts in the currency composition of the holdings of the industrial (as opposed to developing) countries. The growing strength of the Japanese yen and the solidification of the European Monetary System, which boosted the demand for both the French franc and the German mark, appear to have increased the attractions of these alternatives. That trend had been rolled back by 1992, however, reflecting renewed turbulence in the EMS and the collapse of Japan's Bubble Economy. Since then, the dollar's share in global foreign exchange reserves, rather than falling, has continued to rise. ${ }^{5}$

${ }^{5}$ An exception to this rule may be the developing countries in 1997 , which appear to have significantly cut back the share of their foreign-exchange portfolios allocated to dollars. That the substitute for the dollar would appear to be other unspecified currencies gives grounds for caution regarding the reliability of this figure. We return to this issue below. 
The opposite is of true for the other major currencies. The share of the Japanese yen peaked in 1991 at 9 per cent, following a long period of increase in both the yen share and in the fraction of global GDP accounted for by the Japanese economy (Figure 2). Since then, the share of foreign exchange reserves held in the yen has since fallen to little more than half of 1991 levels, reflecting low interest rates on yen-denominated assets and Japan's continuing economic and financial difficulties. The share of exchange reserves held in deutsche marks peaked at 18 per cent at the end of the 1980s and has fallen since, plausibly reflecting the difficulties of German economic and monetary unification (an event evident in Figure 3). The shares of the French franc, the Swiss franc and the Dutch guilder have all declined in the course of the 1990s.

Each of these trends is evident for emerging markets as well as industrial countries. The distinctive feature of the data for the former is the rise in the share of unspecified currencies, gradually over the course of the 1990s and then sharply in 1997. A problem here is that the increase in the unspecified-currencies share and the decline in the shares accounted for by the big seven may reflect data problems rather than actual behavior. IMF (1998) notes that the unspecified-currencies category includes both actual holdings of currencies other than the big seven and also foreign exchange reserves for which no information on currency composition is available from the reporting countries or other sources. Lack of information is a particular problem for transition economies that have recently become members of the Fund.

One way of analyzing possible biases is by excluding countries for which unspecified currencies exceed some upper threshold, say ten per cent of total foreign exchange reserves. Table 2 shows the result, again since 1988. As one would expect, this change in sample 
eliminates the sharp rise in unspecified currencies evident in Table 1 but leaves the other important features of that table unchanged. In particular, the post-1987 fall and (more than complete) recovery of the share of the dollar is still there.

Data like these have generally been analyzed in terms of the changing role of the reserve-currency countries in the world economy. Typically, investigators draw inferences on this relationship from time-series data. One of us (Eichengreen 1998) has estimated a model in which the shares of global output and trade of the U.S., UK, Japan and Germany, and the past international roles of their respective national currencies, influence the current currency composition of reserves. The fraction of world trade and output accounted for by the different reserve currency countries presumably captures the attractiveness of holding their currencies for trade- and financial-market-intervention-related purposes. The lagged currency shares are included as a measure of the importance of the historical roles of the respective currencies, on the grounds that the network-externality characteristic of foreign-currency holdings (Kiyotaki and Matsuyama 1993) builds inertia into currency shares.

The estimates, using annual data for the period 1971-1995, indicate that a one percentage point increase in a reserve-currency country's share of global GDP leads on impact to a 0.8 per cent increase in the share of global foreign exchange reserves held in its currency. A one percentage point increase in its share of global trade has an impact effect about half that size. The long-run effects are larger than the impact effects, underscoring the role of history. The difference between the short- and long-run effects is largest for the dollar but smallest for the yen, again consistent with the notion that history matters for reserve-currency status. The large positive coefficient on the lagged dependent variable, whether the relationship is 
estimated by ordinary-least squares or instrumental variables, underscores how slowly currency composition changes, reflecting the network-externality aspect of the decision. ${ }^{6}$

While this approach can capture changes in the relative positions of the reservecurrency countries in the world economy and their implications for reserve management, it does not provide direct evidence on the stability of the demand for reserves denominated in various currencies, but infers this from the lagged dependent variable. Nor does it speak to changes on the demand side that are potentially of even greater moment, such as changing trade patterns, changes in the direction of capital flows, and changes in capital-account and exchange-rate policies. For this, data on the currency composition of the reserves held by individual countries are required.

\section{Data, Methods and Initial Results}

For this study we used annual data for 84 emerging and transition economies for the period 1979-1996. ${ }^{7}$ Reserves held in the form of different currencies are valued using end-of-

${ }^{6}$ Frenkel and Sondergaard (1999) report very similar results, except they omit the lagged dependent variable.

${ }^{7}$ The composition of the sample was determined by data availability. The sample also changes with IMF membership over the period. 
period exchange rates. In principle they are inclusive of swaps. ${ }^{8}$ The data were compiled from the IMF Statistics Department's confidential database (COFER), the World Bank's World Debt Tables, and the IMF's International Financial Statistics. They were checked for accuracy; outliers were verified or corrected, and extreme values and erratic movements that could not be verified were dropped from the sample.

We estimated separate models for reserves held in dollars, deutsche marks, yen and sterling, each as a share of total dollar, DM, yen, sterling and French franc reserves. ${ }^{9}$ Our basic specification, following DLM, relates the share of foreign exchange reserves held in a particular currency to the currency to which a country pegs (the U.S. dollar and other currency and composite pegs are distinguished), the share of external debt service payments denominated in a particular reserve currency, and the share of the country's external trade (the sum of imports and exports) that is conducted with a particular reserve-currency country. ${ }^{10}$ As in DLM, we take the structure of transactions costs and the scale of a country's anticipated foreign exchange market transactions as the principal determinants of its gross asset positions,

${ }^{8}$ Thus, if a country issued a yen-denominated bond to raise foreign exchange and then swapped the proceeds into dollars, they would report their reserves as in dollars.

${ }^{9} \mathrm{We}$ do not report a separate equation for the share of French francs to avoid violating the implicit adding-up constraints across equations. If we took the share of each of these five currencies in total reserves including minor and unspecified currencies, the fifth equation for the French franc could be estimated without violating the adding-up constraints. Given the aforementioned problems with the data for unspecified currencies, however, we consider it safer to proceed as in the text.

${ }^{10}$ Note that our "other pegs" variable excludes French franc pegs, consistent with the approach adopted in the original DLM study. We do include franc pegs when we run separate equations for franc reserves as a consistency check. 
including its holdings of foreign exchange reserves. Given the number of zero observations, all equations are estimated using Tobit. ${ }^{11}$

The results confirm that a country which pegs to the dollar tends to hold a larger share of its foreign exchange reserves in that currency; that the more it trades with a reservecurrency country, the greater its tendency to hold its reserves in that form; and that the larger the share of its external payments that are denominated in a currency, the greater the tendency for its central bank and government to hold foreign reserves in that currency. Not only does the share of foreign exchange reserves held in dollars depend positively on the presence of a dollar peg, the share of trade with the U.S. and the share of debt service denominated in dollars, but the cross effects are almost uniformly negative. From this it would appear that only debt service in dollars and debt service in DM are complements. In the equation for the DM, the share of debt denominated in dollars similarly enters with a positive sign, but that coefficient is not significantly different from zero at standard confidence levels. The equation for sterling similarly suggests that dollar- and yen- denominated debt may increase rather than reducing the demand for sterling, but the trade shares of the respective countries again appear to be gross substitutes. The same strong substitutability is also evident in the equation for the yen.

To establish the robustness of our results, we also estimated this relationship dropping from the sample all countries for which reserves whose currency composition was unspecified

\footnotetext{
${ }^{11}$ While a country's net foreign asset position in any currency can be negative, the gross asset position is always positive. Since we are attempting to explain the proportions of gross foreign exchange reserves held in different currencies, the dependent variable is always a positive number bound by zero and one. Hence the use of Tobit.
} 
constituted at least 10 per cent of the total (essentially paralleling the composition of Table 2 above). The coefficient estimates and significant levels were virtually unchanged when estimated on this smaller sample. This gives us some confidence that any selectivity introduced by the inability to determine the currency composition of a significant portion of certain countries' reserves is not contaminating our results.

We now break the sample at 1985 to facilitate comparisons with the DLM study and at 1990 in order to highlight what if anything is different about the recent decade characterized by capital-account liberalization and increasing exchange-rate flexibility in emerging markets. (See Figure 4.) The results are shown in Tables 4 and 5.

The picture is one of striking stability. The impact of trade with a reserve-currency country on emerging-market reserve shares in that currency is virtually unchanged between the earlier and later periods. The same is true for the denomination of debt. Again, the picture of stability is especially pronounced if we break the sample in 1989 (Tables 6-7), as we do forthwith. The number of cross effects with negative signs is virtually identical across periods, suggesting that reserve currencies remain substitutes in central bank portfolios to more or less the same extent. This stability may be our most dramatic finding -- if an absence of change can be dramatic. It is reinforced by the fact that the values of most of the independent variables (as distinct from the size of the coefficients) also remain relatively stable over time. ${ }^{12}$

A few changes are worthy of comment. There is a rise in the constant term in the equation for U.S. dollars, reflecting the continued attractiveness of holding reserves in that

${ }^{12}$ Thus, Eichengreen and Frankel (1996) provide evidence on this for the currency composition of long-term debt. One exception to this generalization is the prevalence of currency pegs, as we showed in Figure 4 above and discuss below. 
form, holding observable characteristics of the reserve-holding countries constant. This ceteris-paribus shift into dollars seems to have come at the expense of the mark, the yen, and the pound, but not the franc (by inference from the adding up constraints). However, the tendency for countries with dollar pegs to hold additional reserves in that currency and for countries operating other currency pegs to hold significantly less, so strongly evident in DLM and in our data up through 1985, is no longer so clear in the subsequent period. An obvious interpretation is in terms of reflects the ongoing internationalization of financial markets and its corollary, declining transactions costs, which make it less costly for countries seeking to stabilize their exchange rate against the dollar to intervene using other currencies or to obtain the dollars needed for intervention in return for reserves denominated in other currencies. In fact, we are skeptical of this way of viewing the trend. For one thing, countries operating other currency pegs continue to hold additional marks, yen and pounds. For another, if we break the sample later (in 1989, as in Table 6 and 7), countries with dollar pegs appear to still be holding higher shares of dollar reserves. We are inclined to interpret the absence of a significant effect in Table 4 as reflecting the exceptional turbulence affecting the dollar in the second half of the 1980s, which tended to displace currency shares through arbitrary revaluation and devaluation effects and therefore to disrupt central-bank reserve management..$^{13}$

We can also use these coefficients to infer the impact on the demand for different reserve currencies of the shift toward floating. Since roughly half the minor currencies that are pegged to one of the reserve currencies are pegged to the dollar, the point estimates

\footnotetext{
${ }^{13}$ This is something we commented on at the beginning of Section 2 above.
} 
suggest that the abandonment of currency pegs in favor of greater flexibility will tend to reduce the share of dollars in currency reserves. The same is true, to a greater or lesser extent, for the DM and the pound sterling, while the opposite is true for the yen. It would appear that the demand for reserves held in the dollar, the DM and sterling has been boosted by the tendency for countries to peg to them, and that the yen will benefit from the move to greater flexibility.

\section{Further Findings}

We next seek to take further account of changes affecting the operation of the international monetary system in the recent decade, including the liberalization of capital transactions and of international financial markets.

We add to our basic specification a dummy variable for countries with convertible capital accounts (constructed from the Fund's Exchange and Trade Restrictions annual). For the full sample (Table 8) it appears that developing countries that liberalize their capital accounts have a tendency to alter the currency composition of their exchange reserves in favor of dollars and pounds, the currencies of countries that are home to two particularly active international financial markets. (Both coefficients are significantly different from zero at the 95 per cent confidence level. ${ }^{14}$ ) This shift seems to occur at the expense of the DM and (we infer from the adding-up constraint) the French franc. When we split the sample as in Section 3 above, these results continue to hold for the various subperiods, but there is some sign that

${ }^{14}$ The same results obtain in separate regressions for the advanced-industrial countries, the only difference being the statistical insignificance of the positive coefficient for the U.S. dollar. 
the shift into the dollar and sterling comes in addition at the expense of the yen. Again, it would appear that capital account liberalization works to the advantage of the countries with particularly active international financial markets.

We also attempted to test the impact of interest rates, by adding three month market rates in London, Paris, Frankfurt and Tokyo, all relative to New York, to the basic specification. As shown in Table 9, these did not perform well; most of the coefficients were insignificantly different from zero, although in all three relevant cases (in the equations for the DM, sterling, and the yen) the own interest rate relative to the U.S. was positively signed. The weakness of these results is not surprising. ${ }^{15}$ Reserves held for intervention purposes are usually held in the form of relatively short-term treasury securities. (Hence our use of shortterm interest rates.) But at such short maturities, covered interest rate differentials are virtually zero, meaning that reserve managers are confronted with little if any noticeable difference in yields to which to respond.

\section{EMU and the Demand for Reserves}

The advent of the euro is potentially the most important development since the 1970 s affecting the demand for reserves in different currencies. This has been argued by Bergsten (1997), Alogoskoufis and Portes (1997) and Portes and Rey (1998). 22 million more people live in Euroland and hence will use the euro on an everyday basis, they observe, than live in

${ }^{15}$ And again we obtained essentially identical results in separate regressions for the advanced-industrial countries. 
the United States. The residents of Euroland are even more active in international trade than the residents of the United States: exports plus imports amount to 25 per cent of the output and income of Euroland but only 20 per cent in the United States. The advent of the euro will create an immensely large European financial market, larger even than that of the United States. The market value of the bonds, equities and bank assets issued in EU countries, at the end of 1995, amounted to roughly $\$ 27$ trillion, whereas the comparable figure for the United States was “only" \$23 trillion. This is another argument for why the euro could overtake the dollar.

Data through 1997 do not have much capacity to shed light on these hypotheses, since the advent of the euro was still in doubt even at the end of the sample period. It is suggestive, however, that calendar year 1999 has not seen much evidence of a large-scale shift by emerging markets -- or, for that matter, others -- out of dollars in favor of Euroland currencies. ${ }^{16}$ No such shift has occurred despite the boom in euro-denominated security issues, which has outstripped even the expectations of the new currency's most dedicated proponents.

There are two interpretations of the absence of a shift into European reserve currencies, which have very different implications, respectively, for the future of these relationships. One is that the stability of the demand for dollars, DM and francs in 1999

\footnotetext{
${ }^{16}$ Nor has it been characterized by the kind of sharp appreciation of the European currencies predicted by Bergsten and others, although this could reflect a matching change in the relative supply of euro-denominated assets instead of the absence of a demand shift, insofar as G3 central banks are concerned to avoid large bilateral exchange rate fluctuations. Another explanation is the reduction in the demand for reserves denominated in European currencies by EMU member states themselves; the unwinding of EMU reserves at the beginning of 1999 is described in ECB (1999).
} 
reflects the stability of the underlying determinants of the demand for reserve currencies, as argued above. Some of the central banks with the largest reserves -- those of China and Hong Kong SAR, for example -- continue to peg to the dollar, and all the evidence we have suggest that currency pegs continue to matter for reserve-holding behavior. More generally, the currency composition of central banks' reserves is slow to change because habits are slow to change. In a world of network externalities, no single central bank has an incentive to be first to radically reconfigure its reserve portfolio, so existing reserve shares acquire an element of inertia. Finally, a reputation for pursuing policies of price stability, which is a sine qua non for acquiring reserve-currency status, is something that must be accumulated over time. Until the European Central Bank develops a track record of maintaining price and financial stability, and EU member states demonstrate a political commitment to their new monetary arrangement, other central banks will remain reluctant to shift whole hog into euros. We should thus expect the patterns that have prevailed in the past to continue to prevail in the future and to change only gradually over time.

The other view is that the wholesale shift from the dollar to the euro has only been delayed temporarily by the flight to quality in the wake of Russia's default, by the all-butfailure of Long-Term Capital Management, and by the cyclical weakness of the European economies, all of which have led the euro to underperform. So long as the euro was weak, central bankers in emerging markets were reluctant to shift their portfolios out of dollars. ${ }^{17}$ As Montagon (1999) wrote on the occasion of the Asian Development Bank's annual meeting, "Asian governments, which include five of the world's seven largest holders of

\footnotetext{
${ }^{17}$ In addition, Reuters (1999) reports considerable commentary in China to this effect.
} 
reserves, have cold-shouldered the euro because of its weakness since its launch.” Equally revealing were comments by a senior central bank official from the Philippines, the first Asian country to issue a euro-denominated bond (in March) that her central bank wished to build up its reserves in European currency in anticipation of growing trade and debt transactions with the euro-zone, but that the timing would depend "on how quickly the euro stabilizes."18

Now that the consensus medium-term forecast is for the euro to strengthen against the dollar as growth in Europe accelerates relative to growth in the United States, this longdelayed process of reserve reallocation may finally get underway. As Roach (1999, pp.2-3) writes, "I have had many officials warn me of the coming asset allocation shift out of dollars and into euros...With Asian authorities collectively managing close to $\$ 650$ billion in currency reserves...the implication of this asset allocation shift out of dollar-denominated assets should not be taken lightly. These guys are still overweight in dollars, and believe me, virtually all are thinking about reducing their exposure to the world's largest international debtor."

This paper's evidence and perspective do not suggest, however, a radical reallocation of reserves in the short run. The dollar balances of central banks and other international investors may fall somewhat in the future, just as they rose somewhat in 1997-8, but there is no reason to anticipate a wholesale redistribution.

We can also use our data to estimate the extent to which the reserves of EMU members will fall due to the inauguration of monetary union. With the advent of the single currency, it is no longer necessary for member states to hold reserves to buffer their economies against intra-EMU balance-of-payments shocks, just as it is unnecessary for the

\footnotetext{
${ }^{18}$ Montagon (1999), p.1.
} 
Federal Reserve to hold foreign exchange reserves to smooth disturbances to trade and financial flows between the 50 U.S. states. Since there is no prospect of exchange rate changes within the monetary union, an incipient payments deficit which leads to an incipient rise in local interest rates will induce an offsetting capital inflow from the rest of the monetary union; hence there is no need for reserves to buffer shocks to these accounts. ${ }^{19}$ Some previous authors have suggested that this will precipitate a sharp reduction in Europe's foreign exchange reserves. Early estimates by the European Commission (1990) predicted a decline of foreign exchange holdings under EMU of about one half (since intra-EU trade accounts for roughly half of the external trade of the members of the monetary union). Recent estimates by Frankel and Sondergaard (1999), constructed by regressing European countries' reserve holdings on their imports (and a constant term), and then netting out intra-EU imports to construct predicted values, point to comparable economies. Since reserves held in EU currencies accounted for roughly half of the total reserves of the European System of Central Banks (ESCB) on the eve of EMU, this does not imply the need for the participating central banks to buy or sell reserves (Masson and Turtelboom 1997).

Our results indicate considerably smaller effects, consistent with the overall picture of stability in the demand for reserves. Using data for the industrial countries, we regressed the $\log$ of total reserves on the choice of currency peg, the direction of trade, the openness of the current account, and the log of exports and GDP (Table 10). ${ }^{20}$ Controlling for additional

\footnotetext{
${ }^{19}$ This assumes that monetary union is credible and ignores credit risk, both sovereign and commercial.

${ }^{20}$ The two measures of choice of exchange rate arrangement are flexible rates and pegs (continued...)
} 
determinants of the demand for reserves (in contrast to other authors), the estimated elasticity of reserves with respect to exports ranges from 0.2 (in the 1970s and 1980s) to 0.1 (in the 1990s). This suggests that EMU will reduce the desired reserve holdings of the ESCB by only a fifth to a tenth of the actual decline in reserves caused by the unwinding of intra-EMU currency holdings. ${ }^{21}$ In contrast to earlier predictions, these estimates suggest that Euroland will run persistent current account surpluses and/or import financial capital, the foreign exchange proceeds of which will be substantially absorbed by the ECB, until this shortfall is eliminated.

\section{Additional Issues}

In this section we analyze a number of further issues related to the demand for reserves.

The demand for gold. Our analysis has not explicitly considered gold as an alternative to foreign exchange reserves. In fact, the stability of central banks' demand for

${ }^{20}$ (...continued)

to currencies or composites other than the U.S. dollar and the French franc (including cooperative arrangements like the EMS, which dominate this variable in the industrial-country sample).

${ }^{21}$ The coefficients on the two exchange rate variables suggest that this effect should be interpreted as, if anything, an upper bound. Countries with flexible exchange rates, it would appear from our results, are required to hold additional reserves to buffer their currencies against market turbulence, particular if the comparison is with cooperative arrangements like the EMS. This suggests that the ECB may in fact feel the need to accumulate additional reserves to finance intervention in the foreign exchange market designed to damp down exchange rate fluctuations. 
gold, in the face of pronounced changes in the underlying monetary and financial environment, is among the stronger bits of evidence of the stability of the demand for reserves. Since the 1970s, gold has had no official role in the international monetary system. With the decline of inflation in the advanced industrial countries and institutional reforms, like the strengthening of central bank independence, which have, it is to be hoped, locked in this new low-inflation environment, the attractions of gold as an inflation hedge have diminished. The further articulation of international financial markets has made available a wide variety of financial assets whose risk and return characteristics would appear to dominate those of gold. Central banks seeking to increase the return on their portfolios and to minimize risk may still want to hold the market portfolio (according to the standard mean-variance framework), but they have no more reason to hold gold than, say, antiques.

And yet central banks have been strikingly slow to swap their gold for interest-bearing foreign assets. Some countries, the United States and Italy for example, continue to hold fully half of their international reserves in this form. Overall, the quantity of gold reserves held by IMF members has remained strikingly stable. This is true of industrial countries, developing countries, international debtors and international creditors.

We analyzed this behavior by adding the gold reserves of central banks (from the IMF's Annual Report) to the data analyzed above. We then estimated the determinants of gold reserves as a share of total reserves on a sample of 660 developing-country observations. When we break the sample at 1989 , the results are again consistent with this paper's broader theme that old habits die hard. For the full period, we find that the share of gold in total reserves is highest for countries that peg to the dollar and whose debt is heavily denominated 
in that same currency. In contrast, there is no correlation between the share of gold in reserves on the one hand and other currency pegs and the openness of the capital account. ${ }^{22}$

To be sure, there has been some evidence recently that these habits are beginning to change. Troy ounces of gold held by the central banks of IMF member countries fell by 2 per cent in $1997 .^{23}$ The Belgian and Dutch central banks have sold gold from their vaults, driving down the price. Switzerland announced plans to follow. The Bank of England announced its intention of selling 415 metric tons, more than half its reserves of the metal, and on July $6^{\text {th }}$ 1999 it sold the first 25 tons. The International Monetary Fund announced a plan to sell ten million ounces (which were eventually sold off-market). To some extent, these actions reflected extraordinary factors: European central banks took advantage of the fact that the ECB had assumed their responsibility for exchange rates and financial stability to rationalize their reserve portfolios, while the IMF was constrained by its principal shareholders in raising resources for debt relief from other sources. At the same time, however, they also plausibly reflect the loosening grip of gold over even the conservative mentalite of central bankers.

In mid-1999, the price of gold fell to a 20 year low at $\$ 250$ an ounce, reflecting central banks' presence in the market. In response, 15 European central banks announced in September an agreement to limit their gold sales over the next five years to 2,000 tons, and to

\footnotetext{
${ }^{22}$ We suspect that the importance of dollar pegs reflects the behavior of a relatively small number of countries that both peg to the greenback and hold relatively large amounts of gold (China and Hong Kong SAR)

${ }^{23}$ It anomalously rose by a eight per cent in 1998, but this mainly reflected the return of the gold portion of European Currency Unit reserves by the ECB to the central banks of the 11 founding members of Europe's monetary union.
} 
400 tons in any one year. ${ }^{24}$ Simultaneously, the IMF announced the intention of revaluing its gold reserves rather than selling them on the open market. These exceptional steps can be understood as an attempt to avoid driving down the price of gold as panicked central banks desperately seek to be first through the exit, and as a way of indirectly taking back the aid extended to highly-indebted poor — but also gold-producing — countries. The provide yet another example of the power of the forces preventing radical changes in the composition of the reserve base of the international monetary system.

Precautionary reserves and short term debt. Feldstein (1999) has encouraged emerging markets to accumulate foreign exchange reserves as insurance against the disruptive effects of abrupt capital outflows. Greenspan (1999) similarly has suggested that countries hold reserves equal to all the short-term debt scheduled to fall due over the next 12 months. They point to the success of countries with substantial reserves (Taiwan Province of China for example) in withstanding the Asian crisis.

The data suggest that there may be something to this argument. Paralleling the analysis in Table 10 for the industrial countries, we used our developing-country sample to regress the (log of) total reserves (gold reserves plus foreign exchange reserves) on the same explanatory variables as above, and adding the log of total exports and the log of GDP (two measures of economic size). We were interested in whether there has in fact been a tendency for countries with open capital accounts and therefore vulnerable to abrupt capital outflows to hold relatively large reserves. The results are shown in Table 11. The second column

\footnotetext{
${ }^{24}$ Since the UK and Switzerland between them have already committed to selling approximately 1,700 tons, this would appear to leave only 300 tons for the other 12 central banks.
} 
suggests some tendency for developing countries with open capital accounts to hold additional reserves in the 1970s and 1980s. ${ }^{25}$ This propensity is then reversed in the 1990s, with developing countries with open capital accounts holding fewer reserves than other emerging markets. This is at least a hint that the crisis problem of the 1990s reflects not just the opening of capital accounts but pursuit of that policy in conjunction with a failure to accumulate adequate reserves.

That said, there are reasons to question the Feldstein-Greenspan recommendation. Holding reserves against short-term external liabilities is expensive, since U.S. treasury bonds bear lower interest rates than Thai or Korean bank deposits. As Grenville (1999, p.6) has put it, Greenspan's advice "raises the issue of why this short-term debt was useful in the first place, if the proceeds of the short-term borrowing have to be stacked away in reserves (at a lower rate of return than the cost of borrowing)." If short-term foreign borrowing comes with risks that are expensive to insure against, wouldn't it be better to simply avoid it in the first place? The economist's preference for interior solutions would suggest operating a bit on both margins (holding more reserves but also doing more to limit short-term debt).

Second, even large reserves are small relative to the liquidity of the markets. A confidence crisis can cause investors to try to transfer abroad not only short-term foreign liabilities but the whole of M2. Converting these claims into foreign currency is likely to be impossibly expensive for a government or central bank seeking to support a currency peg. This skepticism should not, of course, be taken too far. Given that emerging markets always

${ }^{25}$ Although the coefficient on the relevant variable does not differ significantly from zero at standard confidence levels. 
lose access to borrowed funds in a crisis, they will value some means of smoothing any necessary exchange rate adjustments. ${ }^{26}$

Finally, as suggested by Dooley (1997), large reserves can lend encouragement to the carry trade. Interest rates tend to be lower in the major money centers than in an emerging market that has recently stabilized and opened its capital account, encouraging foreign investors to funnel money into the country. The larger reserves, the more confidence investors will have that they will be able to get out without suffering losses when sentiment turns and the banking system comes under pressure. Hence, the greater will be bank-to-bank lending, and the higher will be the social costs of a banking crisis.

While we acknowledge the validity of this point, the first-best solution to this problem would seem to be to use prudential supervision and regulation to limit the issuance of liabilities by insured financial institutions, and to impose taxes on capital inflows (imperfect though they are) to limit the build-up of short-term debt in other sectors, rather than to hold such a lower stock of reserves as to leave the country vulnerable to even relatively modest shocks. Notwithstanding the above-mentioned caveats, we still expect countries, once they recover from the recent crisis, to hold larger stocks of reserves than before.

\section{Conclusions and Implications}

\footnotetext{
${ }^{26}$ This assumes, of course, that they are smart enough not to try to defend an overvalued exchange rate to the last dollar of reserves.
} 
The currency composition of international reserves has not received the same attention as other aspects of the structure and operation of the international monetary system. In this paper we have reviewed their composition in the 1970s, 1980s and 1990s and analyzed what we regard as the important issues looking forward. Contrary to the predictions of some other authors, we do not detect radical shifts in the currency composition of reserves over time. The choice of reserve asset by developing countries continues to be influenced by a dense web of exchange rate, financial and commercial links with the reserve-currency countries, which itself continues to develop gradually over time. To be sure, there are ongoing changes in these relationships and policies, notably the shift toward increased capital mobility, which appears to work in favor of the dollar and sterling, the currencies of two countries that are home to particularly large and active international financial markets, and toward greater exchange-rate flexibility, which would appear to work against the dollar and the European currencies, to which emerging markets have traditionally pegged, and in favor of the yen. But these are evolutionary processes, which again suggests that the currency composition of reserves will change gradually, not discontinuously. There are plenty of potential sources of instability affecting exchange rates and the international monetary system. But, EMU or not, instability in the demand for reserves seems unlikely to be one of them. 


\section{References}

Alogoskoufis, George, and Richard Portes (1997), "The Euro, the Dollar, and the International Monetary System," in Paul R. Masson, Thomas H. Krueger and Bart G. Turtelboom (eds), EMU and the International Monetary System, Washington, D.C.: International Monetary Fund.

Bergsten, C. Fred (1997), "The Impact of the Euro on Exchange Rates and International Policy Coordination," in Paul R. Masson, Thomas H. Krueger and Bart G. Turtelboom (eds), EMU and the International Monetary System, Washington, D.C.: International Monetary Fund.

Bordo, Michael and Barry Eichengreen (1998), "The Rise and Fall of a Barbarous Relic: The Role of Gold in the International Monetary System," NBER Working Paper no. 6436 (March).

Dooley, Michael P. (1997), “A Model of Crises in Emerging Markets,” NBER Working Paper no. 6300 (December).

Dooley, Michael P., J. Saul Lizondo and Donald J. Mathieson (1989), "The Currency

Composition of Foreign Exchange Reserves," IMF Staff Papers 36, pp.385-434.

Eichengreen, Barry (1998), "The Euro as a Reserve Currency," Journal of the Japanese and International Economies 12, pp.483-506.

Eichengreen, Barry and Jeffrey Frankel (1996), "The SDR, Reserve Currencies, and the Future of the International Monetary System," in Michael Mussa, James Boughton and Peter Isard (eds), The Future of the SDR in Light of Changes in the International Financial System, Washington, D.C.: IMF, pp.337-377.

European Central Bank (1999), “The International Role of the Euro," Monthly Bulletin 1 (August), pp.31-54.

Feldstein, Martin (1999), "Self-Protection for Emerging Market Economies," NBER Working Paper no. 6907 (January).

Frenkel, Michael and Jens Sondergaard (1999), "How Does EMU Affect the Dollar and the Yen as International Reserve and Investment Currencies?" unpublished manuscript, WHU Koblenz and Georgetown University.

Greenspan, Alan (1999), "Remarks by Chairman of the Board of Governors of the Federal Reserve System before The World Bank Conference on Recent Trends in Reserve Management," Washington, D.C. (29 April). 
Grenville, Stephen (1999), "Financial Crises and Globalisation," Reserve Bank of Australia, http://www.rba.gov.au/speech/sp_dg_150799.pdf .

International Monetary Fund (1999), Annual Report, Washington, D.C.: International Monetary Fund.

Kiyotaki, Nobuhiro, Kiminori Matsuyama and Akihiko Matsui (1993), "Toward a theory of International Currency," Review of Economic Studies 60, pp.283-307.

Masson, Paul and Bart Turtelboom (19970, "Characteristics of the Euro, the Demand for Reserves, and International Policy Coordination Under EMU," in Paul Msson, Thomas Krueger and Bart Turtelboom (eds), EMU and the International Monetary System, Washington, D.C.: International Monetary Fund, pp.194-224.

Montagon, Peter (1999), “Asia Spurns Weak Euro in Favour of Dollar," Financial Times 3 May, p.1.

Portes, Richard and Helene Rey (1998), "The Emergence of the Euro as an International Currency,” NBER Working Paper no. 6424 (February).

Reuters (1999), “China Eyes Euro Reserves Despite Weakness,” April 12, 6:42 Eastern time, http://biz/yahoo.com/rf/990412/dp.html.

Roach, Stephen (1999), “Alan Greenspan, Where are You?” Global Economic Forum (14 October), http://www.ms.com/GEFdata/digests/latest-digest.html.

Roger, Scott (1993), "The Management of Foreign Exchange Reserves," BIS Economic Paper no. 38, Basle: BIS (July). 
Table 1

Share of National Currencies in Total Identified Official Holdings of Foreign Exchange, End of Year 1989-98

\begin{tabular}{|c|c|c|c|c|c|c|c|c|c|c|}
\hline & 1989 & 1990 & 1991 & 1992 & 1993 & 1994 & 1995 & 1996 & 1997 & 1998 \\
\hline \multicolumn{11}{|l|}{ All Countries } \\
\hline US dollar & 51.3 & 47.8 & 48.3 & 51.9 & 53.0 & 53.0 & 54.0 & 56.9 & 57.1 & 60.3 \\
\hline Pound sterling & 2.3 & 2.8 & 3.1 & 2.9 & 2.8 & 3.1 & 3.0 & 3.2 & 3.3 & 3.9 \\
\hline Deutsche mark & 17.8 & 16.5 & 15.1 & 13.0 & 13.4 & 13.8 & 13.2 & 12.5 & 12.3 & 12.1 \\
\hline French franc & 1.4 & 2.2 & 2.7 & 2.4 & 2.1 & 2.3 & 2.2 & 1.7 & 1.3 & 1.3 \\
\hline Swiss franc & 1.4 & 1.2 & 1.1 & 1.0 & 1.1 & 0.9 & 0.7 & 0.7 & 0.6 & 0.7 \\
\hline Netherlands guilder & 1.1 & 1.0 & 1.0 & 0.6 & 0.6 & 0.5 & 0.4 & 0.3 & 0.4 & 0.4 \\
\hline Japanese yen & 7.2 & 7.7 & 8.3 & 7.3 & 7.3 & 7.5 & 6.2 & 5.5 & 4.8 & 5.1 \\
\hline Ecu & 10.8 & 9.7 & 10.2 & 9.7 & 8.2 & 7.7 & 6.8 & 5.9 & 5.1 & 0.8 \\
\hline Unspecified currencies & 6.7 & 11.1 & 10.2 & 11.3 & 11.6 & 11.3 & 13.5 & 13.2 & 15.1 & 15.5 \\
\hline \multicolumn{11}{|l|}{ Industrial Countries } \\
\hline US dollar & 47.9 & 44.9 & 43.1 & 48.4 & 49.9 & 50.8 & 51.8 & 56.1 & 57.9 & 64.3 \\
\hline Pound sterling & 1.1 & 1.4 & 1.6 & 2.2 & 2.0 & 2.3 & 2.1 & 2.0 & 1.9 & 3.1 \\
\hline Deutsche mark & 20.4 & 19.4 & 18.0 & 14.9 & 16.2 & 16.3 & 16.4 & 15.6 & 15.9 & 14.7 \\
\hline French franc & 1.1 & 2.3 & 3.0 & 2.8 & 2.5 & 2.4 & 2.3 & 1.7 & 0.9 & 1.4 \\
\hline Swiss franc & 1.1 & 0.9 & 0.8 & 0.4 & 0.3 & 0.2 & 0.1 & 0.1 & 0.1 & 0.2 \\
\hline Netherlands guilder & 1.1 & 1.1 & 1.1 & 0.4 & 0.4 & 0.3 & 0.2 & 0.2 & 0.2 & 0.3 \\
\hline Japanese yen & 7.4 & 8.5 & 9.5 & 7.5 & 7.7 & 8.2 & 6.6 & 5.6 & 5.7 & 7.9 \\
\hline Ecu & 15.3 & 14.5 & 16.6 & 16.7 & 15.2 & 14.6 & 13.4 & 12.0 & 10.9 & 1.8 \\
\hline Unspecified currencies & 4.5 & 6.9 & 6.3 & 6.7 & 5.8 & 5.0 & 7.0 & 6.7 & 6.4 & 7.3 \\
\hline \multicolumn{11}{|l|}{ Developing Countries } \\
\hline US dollar & 59.6 & 53.7 & 56.4 & 56.7 & 56.7 & 55.5 & 56.1 & 57.7 & 56.5 & 57.1 \\
\hline Pound sterling & 5.3 & 5.5 & 5.3 & 3.8 & 3.6 & 4.0 & 4.0 & 4.4 & 4.5 & 4.6 \\
\hline Deutsche mark & 11.4 & 10.4 & 10.5 & 10.3 & 10.0 & 10.9 & 9.9 & 9.6 & 9.3 & 10.1 \\
\hline French franc & 2.1 & 2.1 & 2.2 & 1.9 & 1.7 & 2.2 & 2.0 & 1.8 & 1.6 & 1.2 \\
\hline Swiss franc & 2.2 & 1.8 & 1.8 & 1.8 & 2.0 & 1.6 & 1.3 & 1.2 & 1.0 & 1.0 \\
\hline Netherlands guilder & 0.9 & 0.8 & 0.9 & 0.9 & 0.8 & 0.7 & 0.5 & 0.5 & 0.5 & 0.4 \\
\hline Japanese yen & 6.6 & 6.0 & 6.4 & 7.1 & 6.8 & 6.7 & 5.7 & 5.4 & 4.0 & 3.7 \\
\hline $\mathrm{Ecu}$ & - & - & - & - & - & - & - & - & - & - \\
\hline Unspecified currencies & 12.0 & 19.8 & 16.5 & 17.6 & 18.5 & 18.3 & 20.3 & 19.4 & 22.7 & 21.9 \\
\hline
\end{tabular}

Source: 1998 IMF Annual Report. 
$-29-$

Table 2. Share of National Currencies in Total Identified Official Holdings of Foreign Exchange, Excluding Countries with Unspecified Currencies Greater than 10 Per Cent

End of Year 1989-1997.

\begin{tabular}{|c|c|c|c|c|c|c|c|c|c|}
\hline & 1989 & 1990 & 1991 & 1992 & 1993 & 1994 & 1995 & 1996 & 1997 \\
\hline \multicolumn{10}{|l|}{ All Countries } \\
\hline US dollar & 67.9 & 62.1 & 62.3 & 62.4 & 61.9 & 64.2 & 73.6 & 72.5 & 78.4 \\
\hline Pound sterling & 1.3 & 1.9 & 1.9 & 2.5 & 2.3 & 2.7 & 1.8 & 2.4 & 1.7 \\
\hline Deutsche mark & 17.9 & 20.3 & 17.8 & 16.1 & 19.2 & 18.1 & 14.8 & 15.4 & 13.7 \\
\hline French franc & 0.6 & 0.8 & 1.0 & 2.8 & 2.4 & 2.7 & 1.6 & 1.9 & 1.1 \\
\hline Japanese yen & 11.1 & 13.8 & 15.5 & 15.1 & 12.8 & 11.8 & 7.5 & 6.6 & 3.8 \\
\hline Unspecified Currencies & 1.2 & 1.1 & 1.4 & 1.1 & 1.4 & 0.6 & 0.8 & 1.1 & 1.2 \\
\hline \multicolumn{10}{|l|}{ Industrial Countries } \\
\hline US dollar & 67.2 & 61.4 & 59.9 & 61.2 & 61.3 & 66.2 & 73.9 & 70.9 & 86.1 \\
\hline Pound sterling & 0.5 & 0.4 & 0.5 & 2.1 & 1.9 & 2.9 & 1.9 & 3.0 & 0.8 \\
\hline Deutsche mark & 20.2 & 22.4 & 21.1 & 18.0 & 20.5 & 15.8 & 12.9 & 14.8 & 9.0 \\
\hline French franc & 0.0 & 0.0 & 0.0 & 2.5 & 2.1 & 2.7 & 1.7 & 2.3 & 0.4 \\
\hline Japanese yen & 11.2 & 14.8 & 17.5 & 15.5 & 13.1 & 12.2 & 8.8 & 7.5 & 2.9 \\
\hline Unspecified Currencies & 0.9 & 1.0 & 0.9 & 0.7 & 1.1 & 0.2 & 0.7 & 1.5 & 0.9 \\
\hline \multicolumn{10}{|l|}{ Developing Countries } \\
\hline US dollar & 67.8 & 61.6 & 64.8 & 65.8 & 69.1 & 66.7 & 73.5 & 74.8 & 68.1 \\
\hline Pound sterling & 6.5 & 8.3 & 6.1 & 3.9 & 3.4 & 3.0 & 2.2 & 2.5 & 2.9 \\
\hline Deutsche mark & 11.8 & 14.7 & 14.1 & 13.5 & 13.8 & 17.7 & 15.1 & 14.4 & 20.1 \\
\hline French franc & 2.4 & 3.6 & 3.8 & 3.0 & 2.7 & 2.7 & 1.8 & 1.3 & 2.0 \\
\hline Japanese yen & 6.5 & 8.3 & 6.1 & 3.9 & 3.4 & 3.0 & 2.2 & 2.5 & 5.1 \\
\hline Unspecified Currencies & 1.6 & 1.3 & 2.0 & 1.7 & 1.8 & 1.5 & 1.1 & 0.9 & 1.7 \\
\hline
\end{tabular}

Source: IMF COFER data base. 
Table 3

Benchmark Regressions

Dependent Variable is Share of Currency in Five Currency Total

(standard error in parentheses)

\begin{tabular}{|c|c|c|c|c|}
\hline Explanatory Variable & US Dollar & German Mark & Japanese Yen & UK Pound \\
\hline Constant & $\begin{array}{l}0.751 \\
(0.040)\end{array}$ & $\begin{array}{l}0.051 \\
(0.027)\end{array}$ & $\begin{array}{l}-0.036 \\
(0.022)\end{array}$ & $\begin{array}{l}-0.020 \\
(0.017)\end{array}$ \\
\hline Other Peg & $\begin{array}{l}-0.001 \\
(0.024)\end{array}$ & $\begin{array}{l}0.093 \\
(0.016)\end{array}$ & $\begin{array}{l}0.042 \\
(0.013)\end{array}$ & $\begin{array}{l}0.036 \\
(0.010)\end{array}$ \\
\hline Dollar Peg & $\begin{array}{l}0.060 \\
(0.028)\end{array}$ & $\begin{array}{l}-0.008 \\
(0.019)\end{array}$ & $\begin{array}{l}-0.047 \\
(0.015)\end{array}$ & $\begin{array}{l}0.002 \\
(0.012)\end{array}$ \\
\hline \multicolumn{5}{|l|}{ Direction of Trade } \\
\hline Share with Germany & $\begin{array}{l}-0.523 \\
(0.203)\end{array}$ & $\begin{array}{l}1.470 \\
(0.135)\end{array}$ & $\begin{array}{l}0.108 \\
(0.110)\end{array}$ & $\begin{array}{l}0.035 \\
(0.088)\end{array}$ \\
\hline Share with France & $\begin{array}{l}-2.437 \\
(0.197)\end{array}$ & $\begin{array}{l}-0.438 \\
(0.140)\end{array}$ & $\begin{array}{l}-0.341 \\
(0.112)\end{array}$ & $\begin{array}{l}-0.170 \\
(0.093)\end{array}$ \\
\hline Share with UK & $\begin{array}{l}-0.362 \\
(0.214)\end{array}$ & $\begin{array}{l}-0.251 \\
(0.145)\end{array}$ & $\begin{array}{l}0.103 \\
(0.119)\end{array}$ & $\begin{array}{l}1.011 \\
(0.091)\end{array}$ \\
\hline Share with US & $\begin{array}{l}0.599 \\
(0.081)\end{array}$ & $\begin{array}{l}-0.355 \\
(0.055)\end{array}$ & $\begin{array}{l}-0.088 \\
(0.044)\end{array}$ & $\begin{array}{l}-0.147 \\
(0.036)\end{array}$ \\
\hline Share with Japan & $\begin{array}{l}-0.599 \\
(0.176)\end{array}$ & $\begin{array}{l}-0.193 \\
(0.117)\end{array}$ & $\begin{array}{l}0.510 \\
(0.090)\end{array}$ & $\begin{array}{l}0.100 \\
(0.075)\end{array}$ \\
\hline \multicolumn{5}{|l|}{ Denomination of Debt } \\
\hline Deutsche Mark & $\begin{array}{l}40.853 \\
(24.251)\end{array}$ & $\begin{array}{l}74.405 \\
(15.904)\end{array}$ & $\begin{array}{l}-5.416 \\
(12.413)\end{array}$ & $\begin{array}{l}4.498 \\
(10.386)\end{array}$ \\
\hline Franc & $\begin{array}{l}-40.481 \\
(13.737)\end{array}$ & $\begin{array}{l}-44.333 \\
(12.492)\end{array}$ & $\begin{array}{l}-9.460 \\
(8.407)\end{array}$ & $\begin{array}{l}-29.746 \\
(8.578)\end{array}$ \\
\hline Pound & $\begin{array}{l}-37.697 \\
(19.392)\end{array}$ & $\begin{array}{l}-23.588 \\
(12.819)\end{array}$ & $\begin{array}{l}-10.956 \\
(10.450)\end{array}$ & $\begin{array}{l}37.024 \\
(8.143)\end{array}$ \\
\hline Dollar & $\begin{array}{l}10.472 \\
(2.898)\end{array}$ & $\begin{array}{l}0.168 \\
(1.932)\end{array}$ & $\begin{array}{l}2.129 \\
(1.513)\end{array}$ & $\begin{array}{l}2.341 \\
(1.237)\end{array}$ \\
\hline Yen & $\begin{array}{l}-32.168 \\
(19.118)\end{array}$ & $\begin{array}{l}48.834 \\
(12.739)\end{array}$ & $\begin{array}{l}84.642 \\
(9.708)\end{array}$ & $\begin{array}{l}17.040 \\
(8.274)\end{array}$ \\
\hline $\mathrm{R}^{2}$ & 0.591 & 0.415 & 0.346 & 0.376 \\
\hline Total Observations & 740 & 740 & 740 & 740 \\
\hline
\end{tabular}


Table 4

Regressions (Period 1979 - 1985)

Dependent Variable is Share of Currency in Five Currency Total

(standard error in parentheses)

\begin{tabular}{|c|c|c|c|c|}
\hline Explanatory Variable & US Dollar & German Mark & Japanese Yen & UK Pound \\
\hline Constant & $\begin{array}{l}0.381 \\
(0.083)\end{array}$ & $\begin{array}{l}0.093 \\
(0.056)\end{array}$ & $\begin{array}{c}0.089 \\
(0.056)\end{array}$ & $\begin{array}{l}0.082 \\
(0.049)\end{array}$ \\
\hline Other Peg & $\begin{array}{l}-0.124 \\
(0.039)\end{array}$ & $\begin{array}{l}0.045 \\
(0.026)\end{array}$ & $\begin{array}{l}0.029 \\
(0.026)\end{array}$ & $\begin{array}{l}0.033 \\
(0.023)\end{array}$ \\
\hline Dollar Peg & $\begin{array}{l}0.200 \\
(0.038)\end{array}$ & $\begin{array}{l}-0.003 \\
(0.026)\end{array}$ & $\begin{array}{l}-0.098 \\
(0.027)\end{array}$ & $\begin{array}{l}-0.0004 \\
(0.0227)\end{array}$ \\
\hline \multicolumn{5}{|l|}{ Direction of Trade } \\
\hline Share with Germany & $\begin{array}{l}0.946 \\
(0.371)\end{array}$ & $\begin{array}{l}1.024 \\
(0.252)\end{array}$ & $\begin{array}{l}-0.064 \\
(0.253)\end{array}$ & $\begin{array}{l}-0.568 \\
(0.218)\end{array}$ \\
\hline Share with France & $\begin{array}{l}-1.927 \\
(0.325)\end{array}$ & $\begin{array}{l}-0.984 \\
(0.244)\end{array}$ & $\begin{array}{l}-0.988 \\
(0.246)\end{array}$ & $\begin{array}{l}-0.380 \\
(0.216)\end{array}$ \\
\hline Share with UK & $\begin{array}{l}-0.551 \\
(0.322)\end{array}$ & $\begin{array}{l}-0.189 \\
(0.218)\end{array}$ & $\begin{array}{l}0.053 \\
(0.223)\end{array}$ & $\begin{array}{l}1.094 \\
(0.189)\end{array}$ \\
\hline Share with US & $\begin{array}{l}0.744 \\
(0.148)\end{array}$ & $\begin{array}{l}-0.281 \\
(0.101)\end{array}$ & $\begin{array}{l}-0.205 \\
(0.102)\end{array}$ & $\begin{array}{l}-0.253 \\
(0.088)\end{array}$ \\
\hline Share with Japan & $\begin{array}{l}-0.026 \\
(0.254)\end{array}$ & $\begin{array}{l}-0.044 \\
(0.170)\end{array}$ & $\begin{array}{l}0.156 \\
(0.163)\end{array}$ & $\begin{array}{l}-0.206 \\
(0.088)\end{array}$ \\
\hline \multicolumn{5}{|l|}{ Denomination of Debt } \\
\hline Deutsche Mark & $\begin{array}{l}-50.894 \\
(49.847)\end{array}$ & $\begin{array}{l}159.352 \\
(33.212)\end{array}$ & $\begin{array}{l}-32.582 \\
(34.031)\end{array}$ & $\begin{array}{l}40.017 \\
(29.162)\end{array}$ \\
\hline Franc & $\begin{array}{l}-44.664 \\
(19.972)\end{array}$ & $\begin{array}{l}-25.208 \\
(20.420)\end{array}$ & $\begin{array}{l}-2.208 \\
(12.694)\end{array}$ & $\begin{array}{l}-51.010 \\
(21.837\end{array}$ \\
\hline Pound & $\begin{array}{l}26.121 \\
(24.762)\end{array}$ & $\begin{array}{l}-26.564 \\
(16.730)\end{array}$ & $\begin{array}{l}-40.134 \\
(18.197)\end{array}$ & $\begin{array}{l}17.607 \\
(14.337\end{array}$ \\
\hline Dollar & $\begin{array}{l}19.243 \\
(3.981)\end{array}$ & $\begin{array}{l}-4.815 \\
(2.676)\end{array}$ & $\begin{array}{l}1.812 \\
(2.672)\end{array}$ & $\begin{array}{l}0.443 \\
(2.323)\end{array}$ \\
\hline Yen & $\begin{array}{l}4.489 \\
(31.651)\end{array}$ & $\begin{array}{l}59.894 \\
(21.173)\end{array}$ & $\begin{array}{l}56.596 \\
(20.244)\end{array}$ & $\begin{array}{l}12.636 \\
(18.915)\end{array}$ \\
\hline $\mathrm{R}^{2}$ & 0.684 & 0.356 & 0.226 & 0.410 \\
\hline Total Observations & 280 & 280 & 280 & 280 \\
\hline
\end{tabular}


Table 5

Regressions (Period 1986 - 1997)

Dependent Variable is Share of Currency in Five Currency Total

(standard error in parentheses)

\begin{tabular}{|c|c|c|c|c|}
\hline Explanatory Variable & US Dollar & German Mark & Japanese Yen & UK Pound \\
\hline Constant & $\begin{array}{l}0.795 \\
(0.047)\end{array}$ & $\begin{array}{l}0.043 \\
(0.031)\end{array}$ & $\begin{array}{l}-0.072 \\
(0.023)\end{array}$ & $\begin{array}{l}-0.045 \\
(0.017)\end{array}$ \\
\hline Other Peg & $\begin{array}{l}-0.027 \\
(0.031)\end{array}$ & $\begin{array}{l}0.110 \\
(0.030)\end{array}$ & $\begin{array}{l}0.050 \\
(0.014)\end{array}$ & $\begin{array}{l}0.030 \\
(0.011)\end{array}$ \\
\hline Dollar Peg & $\begin{array}{l}0.035 \\
(0.044)\end{array}$ & $\begin{array}{l}-0.066 \\
(0.030)\end{array}$ & $\begin{array}{l}-0.003 \\
(0.020)\end{array}$ & $\begin{array}{l}-0.007 \\
(0.015)\end{array}$ \\
\hline \multicolumn{5}{|l|}{ Direction of Trade } \\
\hline Share with Germany & $\begin{array}{l}-0.900 \\
(0.234)\end{array}$ & $\begin{array}{l}1.636 \\
(0.154)\end{array}$ & $\begin{array}{l}0.104 \\
(0.112)\end{array}$ & $\begin{array}{l}0.021 \\
(0.083)\end{array}$ \\
\hline Share with France & $\begin{array}{l}-2.497 \\
(0.257)\end{array}$ & $\begin{array}{l}-0.148 \\
(0.162)\end{array}$ & $\begin{array}{l}-0.097 \\
(0.117)\end{array}$ & $\begin{array}{l}-0.085 \\
(0.089)\end{array}$ \\
\hline Share with UK & $\begin{array}{l}0.059 \\
(0.288)\end{array}$ & $\begin{array}{l}-0.194 \\
(0.196)\end{array}$ & $\begin{array}{l}0.061 \\
(0.142)\end{array}$ & $\begin{array}{l}0.857 \\
(0.099)\end{array}$ \\
\hline Share with US & $\begin{array}{l}0.534 \\
(0.099)\end{array}$ & $\begin{array}{l}-0.284 \\
(0.066)\end{array}$ & $\begin{array}{l}-0.086 \\
(0.047)\end{array}$ & $\begin{array}{l}-0.106 \\
(0.035)\end{array}$ \\
\hline Share with Japan & $\begin{array}{l}-0.592 \\
(0.256)\end{array}$ & $\begin{array}{l}-0.535 \\
(0.167)\end{array}$ & $\begin{array}{l}0.860 \\
(0.115)\end{array}$ & $\begin{array}{l}0.313 \\
(0.088)\end{array}$ \\
\hline \multicolumn{5}{|l|}{ Denomination of Debt } \\
\hline Deutsche Mark & $\begin{array}{l}64.051 \\
(28.440)\end{array}$ & $\begin{array}{l}53.238 \\
(18.165)\end{array}$ & $\begin{array}{l}0.361 \\
(12.473)\end{array}$ & $\begin{array}{l}-6.090 \\
(9.708)\end{array}$ \\
\hline Franc & $\begin{array}{l}-24.227 \\
(21.773)\end{array}$ & $\begin{array}{l}-51.971 \\
(14.966)\end{array}$ & $\begin{array}{l}-14.566 \\
(10.393)\end{array}$ & $\begin{array}{l}-19.480 \\
(8.198)\end{array}$ \\
\hline Pound & $\begin{array}{l}-75.641 \\
(27.780)\end{array}$ & $\begin{array}{l}-19.464 \\
(17.948)\end{array}$ & $\begin{array}{l}-0.440 \\
(12.599)\end{array}$ & $\begin{array}{l}47.917 \\
(9.344)\end{array}$ \\
\hline Dollar & $\begin{array}{l}16.414 \\
(5.489)\end{array}$ & $\begin{array}{l}-4.316 \\
(3.623)\end{array}$ & $\begin{array}{l}5.650 \\
(2.467)\end{array}$ & $\begin{array}{l}3.282 \\
(1.897)\end{array}$ \\
\hline Yen & $\begin{array}{l}-62.508 \\
(24.659)\end{array}$ & $\begin{array}{l}63.903 \\
(15.962)\end{array}$ & $\begin{array}{l}74.934 \\
(10.798)\end{array}$ & $\begin{array}{l}7.063 \\
(8.419)\end{array}$ \\
\hline $\mathrm{R}^{2}$ & 0.575 & 0.500 & 0.502 & 0.405 \\
\hline Total Observations & 460 & 460 & 460 & 460 \\
\hline
\end{tabular}


Table 6

Regressions (Period 1979 - 1989)

Dependent Variable is Share of Currency in Five Currency Total

(standard error in parentheses)

\begin{tabular}{|c|c|c|c|c|}
\hline Explanatory Variable & US Dollar & German Mark & Japanese Yen & UK Pound \\
\hline Constant & $\begin{array}{l}0.381 \\
(0.073)\end{array}$ & $\begin{array}{l}0.089 \\
(0.048)\end{array}$ & $\begin{array}{l}0.090 \\
(0.049)\end{array}$ & $\begin{array}{l}0.063 \\
(0.037)\end{array}$ \\
\hline Other Peg & $\begin{array}{l}0.108 \\
(0.031)\end{array}$ & $\begin{array}{l}0.071 \\
(0.021)\end{array}$ & $\begin{array}{l}0.030 \\
(0.021)\end{array}$ & $\begin{array}{l}0.046 \\
(0.016)\end{array}$ \\
\hline Dollar Peg & $\begin{array}{l}0.163 \\
(0.033)\end{array}$ & $\begin{array}{l}0.020 \\
(0.022)\end{array}$ & $\begin{array}{l}-0.080 \\
(0.023)\end{array}$ & $\begin{array}{l}-0.004 \\
(0.017)\end{array}$ \\
\hline \multicolumn{5}{|l|}{ Direction of Trade } \\
\hline Share with Germany & $\begin{array}{l}0.828 \\
(0.302)\end{array}$ & $\begin{array}{l}1.087 \\
(0.202)\end{array}$ & $\begin{array}{l}0.057 \\
(0.206)\end{array}$ & $\begin{array}{l}-0.272 \\
(0.155)\end{array}$ \\
\hline Share with France & $\begin{array}{l}-1.786 \\
(0.280)\end{array}$ & $\begin{array}{l}-0.869 \\
(0.208)\end{array}$ & $\begin{array}{l}-0.936 \\
(0.218)\end{array}$ & $\begin{array}{l}-0.360 \\
(0.161)\end{array}$ \\
\hline Share with UK & $\begin{array}{l}-0.574 \\
(0.271)\end{array}$ & $\begin{array}{l}-0.179 \\
(0.181)\end{array}$ & $\begin{array}{l}0.090 \\
(0.190)\end{array}$ & $\begin{array}{l}0.902 \\
(0.138)\end{array}$ \\
\hline Share with US & $\begin{array}{l}0.897 \\
(0.119)\end{array}$ & $\begin{array}{l}-0.402 \\
(0.082)\end{array}$ & $\begin{array}{l}-0.333 \\
(0.086)\end{array}$ & $\begin{array}{l}-0.231 \\
(0.062)\end{array}$ \\
\hline Share with Japan & $\begin{array}{l}0.015 \\
(0.227)\end{array}$ & $\begin{array}{l}-0.177 \\
(0.151)\end{array}$ & $\begin{array}{l}0.008 \\
(0.148)\end{array}$ & $\begin{array}{l}-0.203 \\
(0.116)\end{array}$ \\
\hline \multicolumn{5}{|l|}{ Denomination of Debt } \\
\hline Deutsche Mark & $\begin{array}{l}24.682 \\
(39.405)\end{array}$ & $\begin{array}{l}156.38 \\
(25.829)\end{array}$ & $\begin{array}{l}-56.483 \\
(26.641)\end{array}$ & $\begin{array}{l}23.388 \\
(19.978)\end{array}$ \\
\hline Franc & $\begin{array}{l}-42.301 \\
(15.463)\end{array}$ & $\begin{array}{l}-23.120 \\
(14.877)\end{array}$ & $\begin{array}{l}-1.277 \\
(12.484)\end{array}$ & $\begin{array}{l}-34.752 \\
(12.954)\end{array}$ \\
\hline Pound & $\begin{array}{l}16.636 \\
(21.065)\end{array}$ & $\begin{array}{l}-24.273 \\
(13.855)\end{array}$ & $\begin{array}{l}-27.707 \\
(14.990)\end{array}$ & $\begin{array}{l}22.936 \\
(10.606)\end{array}$ \\
\hline Dollar & $\begin{array}{l}16.855 \\
(3.569)\end{array}$ & $\begin{array}{l}-4.310 \\
(2.372)\end{array}$ & $\begin{array}{l}2.743 \\
(2.423)\end{array}$ & $\begin{array}{l}0.242 \\
(1.816)\end{array}$ \\
\hline Yen & $\begin{array}{l}-24.641 \\
(22.183)\end{array}$ & $\begin{array}{l}55.129 \\
(15.039)\end{array}$ & $\begin{array}{l}116.758 \\
(12.851)\end{array}$ & $\begin{array}{l}23.156 \\
(11.865)\end{array}$ \\
\hline $\mathrm{R}^{2}$ & 0.665 & 0.369 & 0.317 & 0.414 \\
\hline Total Observations & 420 & 420 & 420 & 420 \\
\hline
\end{tabular}


Table 7

Regressions (1990 - 1997)

Dependent Variable is Share of Currency in Five Currency Total

(standard error in parentheses)

\begin{tabular}{|c|c|c|c|c|}
\hline Explanatory Variable & US Dollar & German Mark & Japanese Yen & UK Pound \\
\hline Constant & $\begin{array}{l}0.396 \\
(0.081)\end{array}$ & $\begin{array}{l}0.087 \\
(0.054)\end{array}$ & $\begin{array}{l}0.071 \\
(0.056)\end{array}$ & $\begin{array}{l}-0.077 \\
(0.044)\end{array}$ \\
\hline Other Peg & $\begin{array}{l}0.132 \\
(0.037)\end{array}$ & $\begin{array}{l}0.055 \\
(0.025)\end{array}$ & $\begin{array}{l}0.027 \\
(0.026)\end{array}$ & $\begin{array}{l}0.033 \\
(0.021)\end{array}$ \\
\hline Dollar Peg & $\begin{array}{l}0.191 \\
(0.037)\end{array}$ & $\begin{array}{l}0.014 \\
(0.025)\end{array}$ & $\begin{array}{l}-0.075 \\
(0.027)\end{array}$ & $\begin{array}{l}-0.004 \\
(0.021)\end{array}$ \\
\hline \multicolumn{5}{|l|}{ Direction of Trade } \\
\hline Share with Germany & $\begin{array}{l}0.719 \\
(0.336)\end{array}$ & $\begin{array}{l}1.068 \\
(0.227)\end{array}$ & $\begin{array}{l}0.026 \\
(0.239)\end{array}$ & $\begin{array}{l}-0.491 \\
(0.182)\end{array}$ \\
\hline Share with France & $\begin{array}{l}-1.803 \\
(0.316)\end{array}$ & $\begin{array}{l}-1.031 \\
(0.240)\end{array}$ & $\begin{array}{l}-0.950 \\
(0.250)\end{array}$ & $\begin{array}{l}-0.442 \\
(0.199)\end{array}$ \\
\hline Share with UK & $\begin{array}{l}-0.735 \\
(0.320)\end{array}$ & $\begin{array}{l}-0.129 \\
(0.215)\end{array}$ & $\begin{array}{l}-0.212 \\
(0.230)\end{array}$ & $\begin{array}{l}1.036 \\
(0.173)\end{array}$ \\
\hline Share with US & $\begin{array}{l}0.799 \\
(0.138)\end{array}$ & $\begin{array}{l}-0.317 \\
(0.095)\end{array}$ & $\begin{array}{l}-0.289 \\
(0.102)\end{array}$ & $\begin{array}{l}-0.241 \\
(0.076)\end{array}$ \\
\hline Share with Japan & $\begin{array}{l}-0.060 \\
(0.251)\end{array}$ & $\begin{array}{l}-0.117 \\
(0.168)\end{array}$ & $\begin{array}{l}0.123 \\
(0.168)\end{array}$ & $\begin{array}{l}-0.213 \\
(0.134)\end{array}$ \\
\hline \multicolumn{5}{|l|}{ Denomination of Debt } \\
\hline Deutsche Mark & $\begin{array}{l}-18.468 \\
(47.926)\end{array}$ & $\begin{array}{l}175.075 \\
(31.795)\end{array}$ & $\begin{array}{l}-51.741 \\
(34.213)\end{array}$ & $\begin{array}{l}36.235 \\
(25.744)\end{array}$ \\
\hline Franc & $\begin{array}{l}-48.471 \\
(18.895)\end{array}$ & $\begin{array}{l}-21.371 \\
(18.156)\end{array}$ & $\begin{array}{l}0.634 \\
(13.514)\end{array}$ & $\begin{array}{l}-38.087 \\
(17.238)\end{array}$ \\
\hline Pound & $\begin{array}{l}24.370 \\
(23.155)\end{array}$ & $\begin{array}{l}-25.716 \\
(15.452)\end{array}$ & $\begin{array}{l}-32.717 \\
(17.109)\end{array}$ & $\begin{array}{l}15.991 \\
(12.342)\end{array}$ \\
\hline Dollar & $\begin{array}{l}18.003 \\
(3.910)\end{array}$ & $\begin{array}{l}-5.919 \\
(2.611)\end{array}$ & $\begin{array}{l}2.684 \\
(2.735)\end{array}$ & $\begin{array}{l}0.306 \\
(2.098)\end{array}$ \\
\hline Yen & $\begin{array}{l}-1.918 \\
(28.566)\end{array}$ & $\begin{array}{l}68.145 \\
(19.178)\end{array}$ & $\begin{array}{l}85.854 \\
(19.204)\end{array}$ & $\begin{array}{l}18.047 \\
(15.825)\end{array}$ \\
\hline $\mathrm{R}^{2}$ & 0.668 & 0.387 & 0.210 & 0.410 \\
\hline Total Observations & 320 & 320 & 320 & 320 \\
\hline
\end{tabular}


Table 8

Basic Specification Plus Measure of Capital Account Convertibility

Dependent Variable is Currency Share in Five Country Total

\begin{tabular}{|c|c|c|c|c|}
\hline Explanatory Variable & US Dollar & German Mark & Japanese Yen & UK Pound \\
\hline Constant & $\begin{array}{l}0.734 \\
(0.041)\end{array}$ & $\begin{array}{l}0.055 \\
(0.028)\end{array}$ & $\begin{array}{l}-0.040 \\
(0.023)\end{array}$ & $\begin{array}{l}-0.030 \\
(0.018)\end{array}$ \\
\hline Other Peg & $\begin{array}{l}-0.001 \\
(0.024)\end{array}$ & $\begin{array}{l}0.093 \\
(0.016)\end{array}$ & $\begin{array}{l}0.042 \\
(0.013)\end{array}$ & $\begin{array}{l}0.036 \\
(0.010)\end{array}$ \\
\hline Dollar Peg & $\begin{array}{l}0.059 \\
(0.028)\end{array}$ & $\begin{array}{l}-0.007 \\
(0.019)\end{array}$ & $\begin{array}{l}-0.047 \\
(0.015)\end{array}$ & $\begin{array}{l}0.002 \\
(0.012)\end{array}$ \\
\hline \multicolumn{5}{|l|}{ Direction of Trade } \\
\hline Share with Germany & $\begin{array}{l}-0.612 \\
(0.208)\end{array}$ & $\begin{array}{l}1.490 \\
(0.138)\end{array}$ & $\begin{array}{l}0.086 \\
(0.113)\end{array}$ & $\begin{array}{l}-0.019 \\
(0.090)\end{array}$ \\
\hline Share with France & $\begin{array}{l}-2.415 \\
(0.197)\end{array}$ & $\begin{array}{l}-0.442 \\
(0.140)\end{array}$ & $\begin{array}{l}-0.338 \\
(0.112)\end{array}$ & $\begin{array}{l}-0.156 \\
(0.092)\end{array}$ \\
\hline Share with UK & $\begin{array}{l}0.352 \\
(0.213)\end{array}$ & $\begin{array}{l}-0.251 \\
(0.145)\end{array}$ & $\begin{array}{l}0.103 \\
(0.119) \\
\end{array}$ & $\begin{array}{l}1.015 \\
(0.090) \\
\end{array}$ \\
\hline Share with US & $\begin{array}{l}0.596 \\
(0.080)\end{array}$ & $\begin{array}{l}-0.354 \\
(0.055)\end{array}$ & $\begin{array}{l}-0.089 \\
(0.044)\end{array}$ & $\begin{array}{l}-0.149 \\
(0.035)\end{array}$ \\
\hline Share with Japan & $\begin{array}{l}-0.554 \\
(0.176) \\
\end{array}$ & $\begin{array}{l}-0.204 \\
(0.118) \\
\end{array}$ & $\begin{array}{l}0.521 \\
(0.091) \\
\end{array}$ & $\begin{array}{l}0.126 \\
(0.075) \\
\end{array}$ \\
\hline \multicolumn{5}{|l|}{ Denomination of Debt } \\
\hline Deutsche Mark & $\begin{array}{l}45.313 \\
(24.285)\end{array}$ & $\begin{array}{l}73.283 \\
(15.959)\end{array}$ & $\begin{array}{l}-4.155 \\
(12.501)\end{array}$ & $\begin{array}{l}7.193 \\
(10.371)\end{array}$ \\
\hline Franc & $\begin{array}{l}-41.032 \\
(13.690)\end{array}$ & $\begin{array}{l}-44.083 \\
(12.471)\end{array}$ & $\begin{array}{l}-9.626 \\
(8.401)\end{array}$ & $\begin{array}{l}-30.111 \\
(8.513)\end{array}$ \\
\hline Pound & $\begin{array}{l}-42.956 \\
(19.521) \\
\end{array}$ & $\begin{array}{l}-22.245 \\
(12.936) \\
\end{array}$ & $\begin{array}{r}-12.463 \\
(10.608) \\
\end{array}$ & $\begin{array}{l}33.899 \\
(8.168) \\
\end{array}$ \\
\hline Dollar & $\begin{array}{l}9.589 \\
(2.924)\end{array}$ & $\begin{array}{l}0.343 \\
(1.945)\end{array}$ & $\begin{array}{l}1.925 \\
(1.531)\end{array}$ & $\begin{array}{l}1.765 \\
(1.245)\end{array}$ \\
\hline Yen & $\begin{array}{l}-36.073 \\
(19.161) \\
\end{array}$ & $\begin{array}{l}49.707 \\
(12.783)\end{array}$ & $\begin{array}{l}83.692 \\
(9.765)\end{array}$ & $\begin{array}{l}14.850 \\
(8.248)\end{array}$ \\
\hline Open Capital Account & $\begin{array}{l}0.040 \\
(0.020)\end{array}$ & $\begin{array}{l}-0.010 \\
(0.014)\end{array}$ & $\begin{array}{l}0.010 \\
(0.011)\end{array}$ & $\begin{array}{l}0.024 \\
(0.009)\end{array}$ \\
\hline $\mathrm{R}^{2}$ & 0.591 & 0.416 & 0.345 & 0.383 \\
\hline Total Observations & 740 & 740 & 740 & 740 \\
\hline
\end{tabular}


Table 9

Basic Specification Plus Interest Rate Effects

Dependent Variable is Currency Share in Five Country Total

\begin{tabular}{|c|c|c|c|c|}
\hline Explanatory Variable & US Dollar & German Mark & Japanese Yen & UK Pound \\
\hline Constant & $\begin{array}{l}0.790 \\
(0.054)\end{array}$ & $\begin{array}{l}0.086 \\
(0.036)\end{array}$ & $\begin{array}{l}-0.020 \\
(0.030)\end{array}$ & $\begin{array}{l}-0.033 \\
(0.024)\end{array}$ \\
\hline Other Peg & $\begin{array}{l}0.011 \\
(0.024)\end{array}$ & $\begin{array}{l}0.093 \\
(0.06)\end{array}$ & $\begin{array}{l}0.043 \\
(0.013)\end{array}$ & $\begin{array}{l}0.036 \\
(0.011)\end{array}$ \\
\hline Dollar Peg & $\begin{array}{l}-0.088 \\
(0.028)\end{array}$ & $\begin{array}{l}-0.011 \\
(0.019)\end{array}$ & $\begin{array}{l}-0.044 \\
(0.016)\end{array}$ & $\begin{array}{l}0.001 \\
(0.012)\end{array}$ \\
\hline \multicolumn{5}{|l|}{ Direction of Trade } \\
\hline Share with Germany & $\begin{array}{l}-0.384 \\
(0.203)\end{array}$ & $\begin{array}{l}1.498 \\
(0.135)\end{array}$ & $\begin{array}{l}0.127 \\
(0.112)\end{array}$ & $\begin{array}{l}0.021 \\
(0.089)\end{array}$ \\
\hline Share with France & $\begin{array}{l}-2.285 \\
(0.197)\end{array}$ & $\begin{array}{l}-0.420 \\
(0.140)\end{array}$ & $\begin{array}{l}-0.321 \\
(0.114)\end{array}$ & $\begin{array}{l}-0.187 \\
(0.093)\end{array}$ \\
\hline Share with UK & $\begin{array}{l}0.237 \\
(0.214)\end{array}$ & $\begin{array}{l}-0.260 \\
(0.145)\end{array}$ & $\begin{array}{l}0.117 \\
(0.121)\end{array}$ & $\begin{array}{l}1.008 \\
(0.092)\end{array}$ \\
\hline Share with US & $\begin{array}{l}0.618 \\
(0.080)\end{array}$ & $\begin{array}{l}-0.322 \\
(0.055)\end{array}$ & $\begin{array}{l}-0.083 \\
(0.045)\end{array}$ & $\begin{array}{l}-0.150 \\
(0.036)\end{array}$ \\
\hline Share with Japan & $\begin{array}{l}-0.401 \\
(0.181)\end{array}$ & $\begin{array}{l}-0.181 \\
(0.120)\end{array}$ & $\begin{array}{l}0.531 \\
(0.095)\end{array}$ & $\begin{array}{l}0.094 \\
(0.078)\end{array}$ \\
\hline \multicolumn{5}{|l|}{ Denomination of Debt } \\
\hline Deutsche Mark & $\begin{array}{l}23.252 \\
(24.562)\end{array}$ & $\begin{array}{l}74.100 \\
(16.053)\end{array}$ & $\begin{array}{l}-6.902 \\
(12.801)\end{array}$ & $\begin{array}{l}5.484 \\
(10.603)\end{array}$ \\
\hline Franc & $\begin{array}{l}-38.283 \\
(13.373)\end{array}$ & $\begin{array}{l}-39.688 \\
(12.150)\end{array}$ & $\begin{array}{l}-9.407 \\
(8.405)\end{array}$ & $\begin{array}{l}-29.021 \\
(8.554)\end{array}$ \\
\hline Pound & $\begin{array}{l}-21.520 \\
(19.683)\end{array}$ & $\begin{array}{l}-14.614 \\
(12.906)\end{array}$ & $\begin{array}{l}-8.031 \\
(10.729)\end{array}$ & $\begin{array}{l}35.080 \\
(8.347)\end{array}$ \\
\hline Dollar & $\begin{array}{l}15.614 \\
(3.227)\end{array}$ & $\begin{array}{l}-0.572 \\
(2.144)\end{array}$ & $\begin{array}{l}2.583 \\
(1.731)\end{array}$ & $\begin{array}{l}2.199 \\
(1.393)\end{array}$ \\
\hline Yen & $\begin{array}{l}-30.254 \\
(19.433)\end{array}$ & $\begin{array}{l}58.348 \\
(12.903)\end{array}$ & $\begin{array}{l}86.353 \\
(10.090)\end{array}$ & $\begin{array}{l}15.229 \\
(8.479)\end{array}$ \\
\hline \multicolumn{5}{|l|}{ Interest Differential } \\
\hline German-US & $\begin{array}{l}0.017 \\
(0.005)\end{array}$ & $\begin{array}{l}0.004 \\
(0.004)\end{array}$ & $\begin{array}{l}0.002 \\
(0.003)\end{array}$ & $\begin{array}{l}0.0001 \\
(0.002)\end{array}$ \\
\hline French-US & $\begin{array}{l}-0.007 \\
(0.004)\end{array}$ & $\begin{array}{l}-0.008 \\
(0.003)\end{array}$ & $\begin{array}{l}-0.001 \\
(0.002) \\
\end{array}$ & $\begin{array}{l}-0.002 \\
(0.002)\end{array}$ \\
\hline UK-US & $\begin{array}{l}-0.021 \\
(0.007)\end{array}$ & $\begin{array}{l}-0.013 \\
(0.005)\end{array}$ & $\begin{array}{l}-0.005 \\
(0.004)\end{array}$ & $\begin{array}{l}0.005 \\
(0.003)\end{array}$ \\
\hline Japan-US & $\begin{array}{l}0.007 \\
(0.008)\end{array}$ & $\begin{array}{l}0.0003 \\
(0.006)\end{array}$ & $\begin{array}{l}0.003 \\
(0.005)\end{array}$ & $\begin{array}{l}-0.004 \\
(0.004)\end{array}$ \\
\hline $\mathrm{R}^{2}$ & 0.602 & 0.433 & 0.344 & 0.385 \\
\hline Total Observations & 740 & 740 & 740 & 740 \\
\hline
\end{tabular}


Table 10

Determinants of Total Reserves, Industrial Countries

Dependent Variable is Log Total Reserves

\begin{tabular}{|c|c|c|c|}
\hline $\begin{array}{l}\text { Explanatory } \\
\text { Variable }\end{array}$ & Full Period & $\begin{array}{l}\text { Through } \\
1990\end{array}$ & After 1990 \\
\hline Constant & $\begin{array}{l}-0.795 \\
(0.404)\end{array}$ & $\begin{array}{l}-1.227 \\
(0.503)\end{array}$ & $\begin{array}{l}2.344 \\
(0.519)\end{array}$ \\
\hline Flexible Rate & $\begin{array}{l}0.180 \\
(0.070)\end{array}$ & $\begin{array}{l}-0.072 \\
(0.095)\end{array}$ & $\begin{array}{l}0.249 \\
(0.076)\end{array}$ \\
\hline Non-\$, non-FF peg & $\begin{array}{l}-0.442 \\
(0.174)\end{array}$ & $\begin{array}{l}-0.218 \\
(0.445)\end{array}$ & $\begin{array}{l}-1.378 \\
(0.170)\end{array}$ \\
\hline \multicolumn{4}{|l|}{ Direction of Trade } \\
\hline Share with Germany & $\begin{array}{l}1.605 \\
(0.380)\end{array}$ & $\begin{array}{l}1.807 \\
(0.513)\end{array}$ & $\begin{array}{l}-0.148 \\
(0.452)\end{array}$ \\
\hline Share with France & $\begin{array}{l}6.311 \\
(0.766)\end{array}$ & $\begin{array}{l}6.080 \\
(1.117)\end{array}$ & $\begin{array}{l}4.123 \\
(0.768)\end{array}$ \\
\hline Share with UK & $\begin{array}{l}2.063 \\
(0.443)\end{array}$ & $\begin{array}{l}2.605 \\
(0.513)\end{array}$ & $\begin{array}{l}-0.481 \\
(0.643)\end{array}$ \\
\hline Share with US & $\begin{array}{l}-0.506 \\
(0.230)\end{array}$ & $\begin{array}{l}-0.527 \\
(0.292)\end{array}$ & $\begin{array}{l}-0.836 \\
(0.259)\end{array}$ \\
\hline Share with Japan & $\begin{array}{l}-1.107 \\
(0.595)\end{array}$ & $\begin{array}{l}0.047 \\
(0.697)\end{array}$ & $\begin{array}{l}-3.344 \\
(0.763)\end{array}$ \\
\hline \multicolumn{4}{|l|}{$\begin{array}{l}\text { Other } \\
\text { Determinants }\end{array}$} \\
\hline $\begin{array}{l}\text { Open Capital } \\
\text { Account }\end{array}$ & $\begin{array}{l}-0.262 \\
(0.076)\end{array}$ & $\begin{array}{l}-0.336 \\
(0.110)\end{array}$ & $\begin{array}{l}0.059 \\
(0.090)\end{array}$ \\
\hline Log Exports & $\begin{array}{l}0.205 \\
(0.079)\end{array}$ & $\begin{array}{l}0.232 \\
(0.105)\end{array}$ & $\begin{array}{l}0.124 \\
(0.086)\end{array}$ \\
\hline Log GDP & $\begin{array}{l}0.593 \\
(0.071)\end{array}$ & $\begin{array}{l}0.600 \\
(0.091)\end{array}$ & $\begin{array}{l}0.482 \\
(0.081)\end{array}$ \\
\hline $\mathrm{R}^{2}$ & 0.888 & 0.886 & 0.939 \\
\hline Total Observations & 340 & 192 & 148 \\
\hline
\end{tabular}


Table 11

Determinants of Total Reserves, Developing Countries

Dependent Variable is Log Total Reserves

\begin{tabular}{|c|c|c|c|}
\hline $\begin{array}{l}\text { Explanatory } \\
\text { Variable }\end{array}$ & Full Period & $\begin{array}{l}\text { Through } \\
1990\end{array}$ & After 1990 \\
\hline Constant & $\begin{array}{l}-1.760 \\
(0.291)\end{array}$ & $\begin{array}{l}-2.642 \\
(0.477)\end{array}$ & $\begin{array}{l}-1.581 \\
(0.368)\end{array}$ \\
\hline Flexible rate & $\begin{array}{l}0.280 \\
(0.099) \\
\end{array}$ & $\begin{array}{l}0.361 \\
(0.136)\end{array}$ & $\begin{array}{l}0.389 \\
(0.143)\end{array}$ \\
\hline Non-\$, non-FF Peg & $\begin{array}{l}-0.265 \\
(0.107)\end{array}$ & $\begin{array}{l}-0.033 \\
(0.140)\end{array}$ & $\begin{array}{l}-0.393 \\
(0.205)\end{array}$ \\
\hline \multicolumn{4}{|l|}{ Direction of Trade } \\
\hline Share with Germany & $\begin{array}{l}1.979 \\
(0.816)\end{array}$ & $\begin{array}{l}4.220 \\
(1.285)\end{array}$ & $\begin{array}{l}0.158 \\
(1.048)\end{array}$ \\
\hline Share with France & $\begin{array}{l}0.679 \\
(0.628)\end{array}$ & $\begin{array}{l}1.560 \\
(0.930)\end{array}$ & $\begin{array}{l}3.298 \\
(0.944)\end{array}$ \\
\hline Share with UK & $\begin{array}{l}0.044 \\
(0.878)\end{array}$ & $\begin{array}{l}1.271 \\
(1.209)\end{array}$ & $\begin{array}{l}-1.303 \\
(1.356) \\
\end{array}$ \\
\hline Share with US & $\begin{array}{l}0.697 \\
(0.317)\end{array}$ & $\begin{array}{l}0.722 \\
(0.508)\end{array}$ & $\begin{array}{l}0.377 \\
(0.424) \\
\end{array}$ \\
\hline Share with Japan & $\begin{array}{l}0.521 \\
(0.693)\end{array}$ & $\begin{array}{l}2.404 \\
(0.948)\end{array}$ & $\begin{array}{l}-0.308 \\
(1.164) \\
\end{array}$ \\
\hline \multicolumn{4}{|l|}{$\begin{array}{l}\text { Other } \\
\text { Determinants }\end{array}$} \\
\hline $\begin{array}{l}\text { Open Capital } \\
\text { Account }\end{array}$ & $\begin{array}{l}-0.098 \\
(0.079)\end{array}$ & $\begin{array}{l}0.125 \\
(0.117)\end{array}$ & $\begin{array}{l}-0.267 \\
(0.105)\end{array}$ \\
\hline Log Exports & $\begin{array}{l}0.624 \\
(0.063)\end{array}$ & $\begin{array}{l}0.775 \\
(0.088)\end{array}$ & $\begin{array}{l}0.406 \\
(0.097)\end{array}$ \\
\hline Log GDP & $\begin{array}{l}0.345 \\
(0.059)\end{array}$ & $\begin{array}{l}0.219 \\
(0.080)\end{array}$ & $\begin{array}{l}0.551 \\
(0.093)\end{array}$ \\
\hline $\mathrm{R}^{2}$ & 0.760 & 0.753 & 0.796 \\
\hline Total Observations & 735 & 420 & 315 \\
\hline
\end{tabular}

